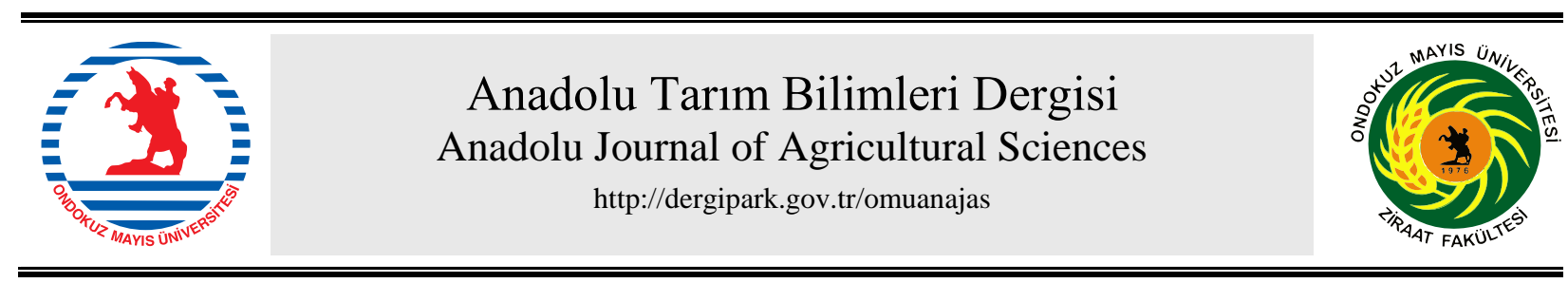

Araştırma/Research

\section{Şeker pancarı tohumlarında depolama koşullarının ve süresinin çimlenme üzerine etkileri}

\author{
(DSongül Gürel* \\ Bolu Abant İzzet Baysal Üniversitesi, Fen Edebiyat Fakültesi, Biyoloji Bölümü 14030 Bolu
}

*Sorumlu yazar/corresponding author: songul.gurel@ibu.edu.tr

Geliş/Received 16/08/2020～Kabul/Accepted 25/09/2020

\section{ÖZET}

Yüksek verim ve kalite standartlarına sahip şeker pancarı (Beta vulgaris L.) üretimi için kaliteli tohumluk kullanılması esastır. Şeker pancarı tohumları ya ham (işlenmemiş) ya da işlenmiş olarak depolanmaktadır. Tohumların depolama ömrü; tohum üretimi sırasında uygulanan kültürel işlemler, çevresel faktörler, çeşidin genetik özelliği, tohumun kimyasal içeriği, tohumun olgunluk düzeyi gibi faktörlerden etkilenmektedir. Bu çalışmada, Türkiye'de üretimi yapılan şeker pancarı tohumlarının 17 y1l süre ile depolanmasının çimlenme oranları üzerine etkileri incelenmiştir. Hasat edildiklerinde \%12 nem içeriğine sahip olan tohumlar, sıcaklığg ve nemi kontrol edilmeyen depolarda saklanmıştır. Depo sıcaklıkları Aralık $\left(1{ }^{\circ} \mathrm{C}\right)$, Ocak $\left(2^{\circ} \mathrm{C}\right)$ ve Şubat $\left(3^{\circ} \mathrm{C}\right)$ aylarında en düşük olurken, Temmuz ve Ağustos aylarında $29^{\circ} \mathrm{C}^{\prime}$ ye yükselmiştir. Deponun nisbi nemi Ocak ayında \%69, Temmuz ve Eylül aylarında ise \%22 olarak kaydedilmiştir. Üretiminden sonra 17 yıl süre ile saklanan 12 farklı partiye ait ham tohumlarda en yüksek çimlenme oranı \%92 ile 3, 6 ve 7 nolu partilerden elde edilmiş ve bu 3 partiye ait işlenmiş tohumlarda ise bu oran $\% 93$ ila \%95 arasında değişmiştir. Uzun süre depolanan tohumların sera testlerinde, bütün tohum partilerinin çimlenme oranları \%82 ila \%94 arasında değişmiştir. Tohumların tarla çıkış oranları, laboratuvar ve sera çimlenme testleri ile bir paralellik göstermiş ve çimlenme oranları \%88 ila \%90 arasında değişmiştir.

\section{Effects of storage conditions and duration on germination in sugar beet seeds}

\section{ABSTRACT}

It is essential to use quality seeds for the production of sugar beet (Beta vulgaris L.) with high yield and quality standards. Sugar beet seeds are stored either raw (unprocessed) or processed form. Logetivity of seeds in storage is affected by cultural processes applied during seed production, environmental factors, genetic characteristics of the variety, chemical content of the seed, and seed maturity status. In this study, the effects of storage period of 17 years on germination of stored sugar beet seeds produced in Turkey were investigated. When harvested, seeds with a moisture content of $12 \%$ were stored in storage whose temperature and humidity parameters were not controlled. While storage temperatures were the lowest in December $\left(1^{\circ} \mathrm{C}\right)$, January $\left(2^{\circ} \mathrm{C}\right)$ and February $\left(3^{\circ} \mathrm{C}\right)$, it increased to $29^{\circ} \mathrm{C}$ in July and August. The relative humidity of the storage was $69 \%$ in January and $22 \%$ in July and September. The highest germination rate of raw seeds, which were stored for 17 years after production was obtained as $92 \%$ from the lots 3, 6 and 7 and 93-95\% in processed seeds of these 3 lots. In the greenhouse tests of stored seeds, the values of germination rates in all seed lots were obtained between $82 \%$ and $94 \%$. Field emergence rates of seeds showed a parallelism with laboratory and greenhouse germination tests, germination rates varying between $88 \%$ and $90 \%$.
Anahtar Sözcükler:

Şeker pancarı Beta vulgaris L. Tohum depolama Tohum ömrü Çimlenme oranı
Keywords: Sugar beet Beta vulgaris L. Seed storage Seed longetivity Germination rate

(C) OMU ANAJAS 2020 


\section{Giriş}

İnsan beslenmesinde önemli bir yere sahip olan şeker, dünyada en çok şeker kamışı (\%76.1) ve şeker pancarı (\%23.9)'ndan üretilmektedir. Türkiye; $A B$, $A B D$ ve Rusya'dan sonra dünyanın dördüncü, $A B$ ve Rusya'dan sonra ise Avrupa'nın üçüncü büyük pancar şekeri üreticisi konumundadır (Sektör Raporu, 2019).

Şeker pancarı iki yıllık bir bitkidir. Birinci yılda vejetatif gelişme göstererek içinde şekerin biriktirildiği kök kısmını oluşturur ve şeker üretimi için hasat edilir. İkinci yılda ise tohuma kalkarak çiçeklenme ve tohum üretiminin sağlandığı generatif gelişme gerçekleşir. Tohum üretimi için bitkilerin 15-20 hafta boyunca 4-10 ${ }^{\circ} \mathrm{C}$ sicaklıklarda vernalize edilmeleri gerekmektedir (Longden, 1986; Milford, 2006). Vernalizasyondan hemen sonra $15{ }^{\circ} \mathrm{C}$ 'nin üzerindeki yüksek sıcaklıklar, bitkileri devernalize ederek bitkilerin vejetatif dönemde kalmasına neden olabilir ve dolayısı ile bu bitkiler çiçek açamaz veya tohum üretemezler. Vernalizasyon gereksinimleri çeşitlere göre farklılık gösterebilmekte ancak Akdeniz iklimlerinde kış ve ilkbahar koşulları genellikle generatif gelişimeyi (tohuma kalkma ve çiçeklenme) indüklemek için yeterli olmaktadır (Kockelmann ve ark., 2011). Vernalizasyondan sonra bitkiler tohum dalı meydana getirmekte ve yaklaşık 5 ay sonra tohum hasadı yapılabilmektedir.

Günümüzde üretilen şeker pancarı bitkilerinin tamamına yakını hibrit çeşitlerdir. $\mathrm{Bu}$ çeşitler aynı zamanda monogerm karakterdedir ve her bir boğumda tek bir çiçek oluşmakta, bundan meydana gelen her bir meyve de sadece bir bitki oluşturmaktadır. Monogerm çeşitlerin şeker pancarı tarımında kullanılması ile bitkilerin teklenmesinde iş̧̧ilik masrafları elimine edilmektedir. Monogerm tohumların ekimi kolay olmakta ve şeker pancarı yetiştiriciliğinde ekim ve bakım işlemlerinde mekanizasyona uygunluk önemli bir avantaj sağlamaktadır.

Yüksek verim ve kaliteye sahip şeker pancarı üretimi için kaliteli tohumluk kullanılması esastır. Tohumların hasatından sonra; temizleme, boyutlandırma, yıkama, kurutma, perikarp (meyve kabuğu) inceltme, parlatma, kaplama veya peletleme gibi işlemler uygulanmaktadır (Sliwinska ve ark., 1999; Kockelmann ve Meyer, 2006; Steinbrecher ve LeubnerMetzger, 2017; Chomontowski ve ark., 2019). Tohum işleme teknolojileri tarlada şeker pancarı üretiminde bitki sayısını garantilemek ve bitkilerin daha güçlü çıkışını sağlamak için uygulanmaktadır (Kockelmann ve Meyer, 2006; Blunk ve ark., 2017). Şeker pancarı tohumları ya ham ya $\mathrm{da}$ işlenmiş olarak depolanmaktadır. Tohumların depolama ömrü; tohum üretimi sırasında uygulanan kültürel işlemler, çevresel faktörler, çeşidin genetik özelliği, tohumun kimyasal içeriği, tohumun olgunluk düzeyi gibi faktörlerden etkilenmektedir (Arın, 2018). Olgunlaşmamış ya da zarar görmüş tohumların depo ömrü kısa olurken, sert tohum kabuğuna sahip tohumlar yumuşak kabuklu tohumlara göre daha uzun süre depolanabilmektedir (Şehirali, 1997). Ayrıca deponun nisbi nemi sıcaklıkla birlikte tohumların depolama ömrünü etkilemektedir. Ayrıca depo hastalıkları ve zararlılarının aktiviteleri ve tohumun nem içeriği de depolama süresini önemli ölçüde etkilemektedir. Şeker pancarında hasatta tohum nemi \%12 ve altında olmalıdır (Sarıpınar, 2011). Tohum depo ömrü üzerine sıcaklık doğrudan etkili olup mümkün olduğu kadar düşük olmalıdır. Depo sıcaklığı yüksek olduğunda embriyoda solunum hizlanmakta ve zararlı organizmaların etkisi artmaktadır. Tohumların nem içeriği, tür ve çeşide, depolama amacına ve süresine, deponun fiziksel yapısına, paketleme materyaline vb. bağlı olarak güvenlik sınırları içerisinde olmalidır (Copeland ve McDonald, 2001). Yüksek tohum nemi (genel olarak \%12-14 üzeri) depo zararlılarının gelişimini ve kızışmayı teşvik ederken, düşük tohum nemi (\%4'ten düşük) tohum canlılığına zarar vermektedir (Arın, 2018). Tohum neminde \%1'lik ve ortam sicaklığındaki $5^{\circ} \mathrm{C}^{\prime}$ lik bir yükselme sonucunda tohum depo ömrü yarıya inmektedir (Harrington, 1973). Ayrıca izolasyonu uygun olmayan depolarda eğer depo iç ve dış sıcaklık farkı yüksek ise depodaki tohumlarda çimlenmenin başlamasına ve tohumlarda mikroorganizma gelişimine neden olmaktadır (Arın, 2018).

Bitkilerin birçoğu düşük sıcaklık ve nem koşullarında saklanabilen tohumlar üretmektedirler. Tohumun uzun ömürlülüğü hakkındaki bilgilerin çoğu, tohumlarla ilgili yapılan yapay yaşlanma deneylerine dayanmaktadır. Bu deneylerde, tohumlar birkaç hafta boyunca yüksek sicaklık ve nem gibi optimum olmayan koşullara maruz bırakılmakta ve tohumların ömrü, tohumun nem içeriği, depolama sicaklığı ve tohum partilerinin karakterlerine göre tahmin edilmektedir (Zinsmeister ve ark., 2020; Walters ve ark., 2005). Bu tür hesaplamalar ile yüksek kaliteli tohumların ideal koşullarda yüz yıllar boyunca canlı kalabileceği tahmin edilmiş ancak bu sonuçların birçoğu uzun süreli depolama çalışmalarında nadiren doğrulanmıştır. Uzun süreli tohum depolaması ex situ gen bankasının korunması için çok önemlidir (Li ve ark., 2009; Long ve ark., 2015). Gen bankaları ürün çeşitliliğini korumakta ve bitki üretimi, araştırma, eğitim ve diğer amaçlar için tohumların kullanımını kolaylaştırmaktadır (Merritt ve ark., 2014; Leprince ve ark., 2017).

Tohum ömrü, tohum depolanmasından sonraki tohum canlılığı olarak tanımlanır (Rajjou ve Debeaujon, 2008). Tohum ömrünü başlıca iki temel faktör belirlemektedir; sıcaklık ve nem içeriği (Priestley, 1986). Depolama sırasındaki yüksek sıcaklıklar, tohumun bozulmasını hızlandırarak depolama ömrünü azaltmaktadır. $\quad 0-50 \quad{ }^{\circ} \mathrm{C}$ arasındaki depolama sıcaklıklarında sıcaklığın her $5{ }^{\circ} \mathrm{C}$ azaltılması ile tohum ömründe iki kat artış sağlanabilmektedir. Bu nedenle 0 $5{ }^{\circ} \mathrm{C}$ arasındaki sıcaklıklar tohum depolaması için uygundur. Uygulamada ise, daha ekonomik olması 
nedeni ile depo sıcaklığının $10{ }^{\circ} \mathrm{C}$ olması çoğunlukla tercih edilmektedir (Arın, 2018).

$\mathrm{Bu}$ araştırmada sıcaklık ve nemin kontrol edilmediği depolarda uzun süre saklanan Ansa isimli ticari şeker pancarı çeşidinin laboratuvar koşullarında çimlendirme testleri yapılmıştır. Ayrıca seralarda ve arazide tohumların çıkış yüzdeleri belirlenmiş ve çimlenme oranlarının zaman içerisindeki değişimleri incelenmiştir.

\section{Materyal ve Yöntem}

\subsection{Bitkisel Materyal}

$\mathrm{Bu}$ çalışmada, ticari bir şeker pancarı çeşidi olan Ansa (KWS, Almanya)'nın tohumları kullanılmıştır. 2001 yllında Türkiye'de üretilen 12 farklı partiye ait ham (işlenmemiş) tohum (Şekil 1a) veya 3 partiye ait işlenmiş tohumlar (Şekil 1b) Türkiye Şeker Fabrikaları A.Ş. Şeker Enstitüsüne ait tohum depolarında saklanmıştır.

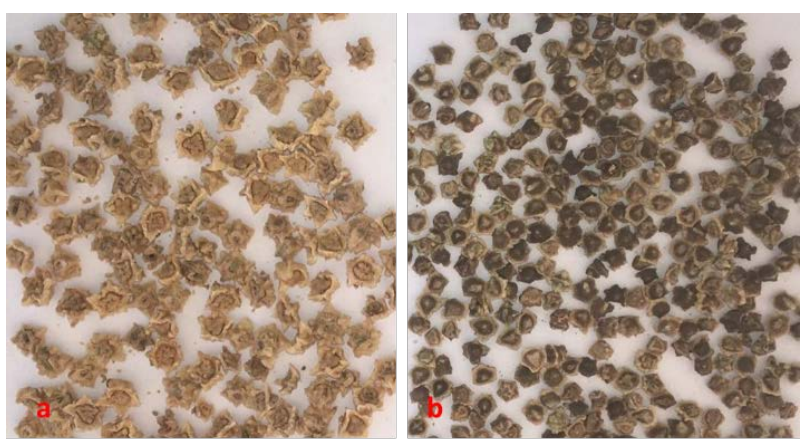

Şekil 1. SSeker pancarı (Beta vulgaris L.) tohumları: a) Ön temizliği yapılmış ham (işlenmemiş) tohum, b) İşlenmiş tohum.

Figure 1. Sugar beet (Beta vulgaris L.) seeds: a) precleaned raw (unprocessed) seeds, b) processed seeds.

Hasadı yapılan ham tohum partilerinin ön temizleme işleminde, içerdikleri sap, saman, çok büyük veya çok küçük şeker pancarı tohumları ile diğer yabancı maddeler, çöp, yabancı ot tohumlarının temizliği yapılmıştır. Ön temizliği yapılan ham şeker pancarı tohumlarının işlenmesi aşamasında dağıtıcı eleme, hava ile ayırma, perikarp inceltme (cilalama), eleme, hava akımıyla ayırma ve gravite eleğiyle ayırma uygulamaları yapılmışıtır. İşlemeye tabi tutulan bu tohumların nem içeriği \%12'nin altında olmuştur.

Şeker pancarı tohumu girintili çıkıntılı olup yüzey şekli düzensizdir ve perikarp (meyve kabuğu) çimlenme inhibitörlerini içermektedir. Bu nedenle işleme sırasında kalın olan perikarp tabakası inceltilmiş ve böylece çimlenmeye engel olan inhibitörler uzaklaştırılmış ve tam dolu, normal büyüklükte ve ağırlıkta olan tohumlar daha sonraki işlemler için ayrılmıştır.

\subsection{Depoların Sicaklı $\left({ }^{\circ} \mathrm{C}\right)$ ve Nem (\%) Değerleri}

Tohumlar sicaklığ 1 ve nemi kontrol edilmeyen depolarda depolanmıştır. Depolama ortamının sıcaklık ve nem değerleri her yıl 12 ay boyunca en düşük ve en yüksek olarak kaydedilmiştir (Çizelge 1 ve Çizelge 2).

Tohumların depo ömrünü etkileyen en önemli etmenler ortamın nem ve sıcaklık değerleridir. En düşük sıcaklık 2013 yılının Aralık ayında $\left(-1{ }^{\circ} \mathrm{C}\right)$ olarak kaydedilmiştir. 2013-2018 yılları arasında ayların ortalamalar dikkate alındığında, en düşük sıcaklıklar 11$12{ }^{\circ} \mathrm{C}$ arasında değişmiştir. En yüksek ortalama sıcaklıklar $18-20{ }^{\circ} \mathrm{C}$ arasında gerçekleşmiştir. Aylara göre ortalamalar dikkate alındığında, en düşük sıcaklık ortalaması Aralık ayında $1{ }^{\circ} \mathrm{C}$ olarak ölçülürken en yüksek sıcaklık ortalaması Temmuz ve Ağustos aylarında $29^{\circ} \mathrm{C}$ olarak kaydedilmiştir. Yine Temmuz ve A ğustos aylarında en yüksek sicaklık $31{ }^{\circ} \mathrm{C}$ olarak gerçekleşmiştir.

Depoların nem oranları yıllara ve aylara göre değişim göstermiştir. 12 ayın ortalamaları dikkate alındığında nisbi nem oranı en düşük 2013 yılında \%27 olurken en yüksek 2014 yılında \%65 olmuştur. Bütün yılların ortalamalarına göre en yüksek nisbi nem oranı Ocak ayında \%69 olurken en düşük nisbi nem oranı Temmuz ve Eylül aylarında \%22 olmuştur. Nisbi nem değeri en yüksek 2016 yılının Şubat ayında \%86, en düşük ise 2013 yılının Mart ayında \%14 olarak gerçekleşmiştir.

\subsection{Laboratuvarda Çimlenme Testleri}

Çimlenme testleri ham tohumlarda 2007; işlenmiş tohumlarda ise 2005 yılından itibaren yapılmıştır. Testler 2018 yılına kadar devam etmiş̧ir. Çimlenme testleri yılda iki kez 6 ay aralıklarla yapılmıştır.

Çimlenme testleri için her bir partiden 400 tohum olacak şekilde örnekler alınarak testler 4 tekerrürlü olarak yürütülmüştür. Her bir tekerrürde 100 tohum kullanılmıştır. Çimlendirilecek tohumlar 4 saat süre ile saf suda ön yıkamaya tabi tutulmuş ve oda sıcaklığında kurutulduktan sonra fungisit ile ilaçlanmıştır. Tohumlar çimlendirme kabında pileli kâğıt arasında, $40 \mathrm{ml}$ saf su ile nemlendirilerek, karanlık koşullarda $20^{\circ} \mathrm{C}$ sicaklığa sahip çimlendirme odasında çimlenmeye bırakılmıştır. 1 $\mathrm{mm}$ kökçük uzunluğuna sahip tohumlar çimlenmiş olarak kabul edilmiş ve sayımlar 14. günde yapılarak, çimlenme oranları (\%) belirlenmiştir. Çimlenme denemeleri ISTA (Uluslararası Tohum Test Birliği) kurallarına göre yapılmıştır (ISTA, 1985) (Şekil 2a).

\subsection{Seralarda Çimlenme Testleri}

2001 y1lında üretilen tohumlar 2015 yilında toprakta çimlenme testine tabi tutulmuştur. Çimlenme denemesinde 15 partinin tohumları kullanılmıştır. Her bir parti için her bir sırada 20 tohum olacak şekilde toplam 400 tohum kullanılmış ve torf içeren kasalara ekimler yapılmıştır. Çimlenme testleri serada $25{ }^{\circ} \mathrm{C}$ sıcaklıkta yürütülmüştür. Tohumlar $2 \mathrm{~cm}$ derinliğe ekilmiştir. 14. gün sonunda çıkan bitkiler sayılarak çıkış oranı (\%) hesaplanmıştır. Çıkış oranı, kotiledon yaprakları toprak yüzeyine çıkan bitkilerin sayılması ile belirlenmiştir (Şekil 2b). 


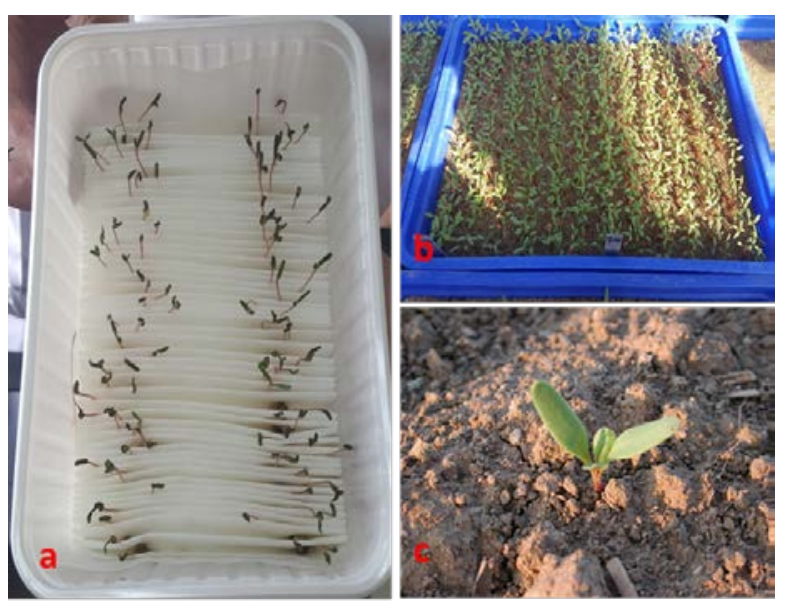

Şekil 2. Şeker pancarı (Beta vulgaris L.) tohumlarının çimlenmesi; a) Laboratuvarda çimlendirme testi, b) Seralarda toprakta çimlendirme testi, c) Tarlada çimlendirme testi.

Figure 2. Germination of sugar beet (Beta vulgaris L.) seeds; a) Germination test in laboratory, b) Germination test in soil in greenhouse, c) Germination test in field

\subsection{Tarla Koşullarında Çimlenme Denemeleri}

Tohum depolarında işlenmiş olarak depolanan 10 partiye ait tohumlar denemelerde kullanılmıştır. Her bir partiye ait tohum örnekleri, ilaçlandıktan sonra ekimler yapılmıștır. Tarla denemeleri Eskișehir ve Ilgın (Konya) lokasyonlarında 4 tekerrürlü olarak kurulmuş ve çimlenen bitki sayımları ilk bitkilerin çıkışından sonraki 21. günde yapılmıştır (Şekil 2c).

\section{Bulgular ve Tartışma}

\subsection{Laboratuvarda Çimlenme Testleri}

\subsubsection{Işlenmemiş tohumlarda çimlenme oranlart}

Farklı partilere ait tohum örneklerinde yapılan çimlenme testlerinde sayımlar 14. günde yapılmıştır. İşlenmemiş tohumlarda sayımlar 2007 ile 2018 yılları arasında yapılan çimlenme testlerine göre en yüksek çimlenme oranı $\% 95$ ile 3 nolu partinin tohumlarında 2007 ile 2008 yıllarında elde edilmiştir. 1 nolu partinin tohumlarında 2010 yılında yapılan çimlenme testlerinde $\% 82$ çimlenme oranı ile en düşük değer elde edilmiştir. $\mathrm{Bu}$ partinin tohumlarında çimlenme oranları \%82-87 arasında gerçekleşmiştir (Çizelge 3). Üretim yılı farklı olan 1 nolu partinin çimlenme oranlarının düşük olması, depolama ömrünün tohumun başlangıç kalitesine bağlı olduğunu ve farklı yıllarda üretilen tohumlar arasındaki çimlenme oranı farklıl1kları tohum üretimi sırasında uygulanan kültürel işlemler ve çevresel faktörlerin (özellikle stres koşulları), tohumun depo ömrünü etkilediğini belirten Rao ve ark. (2017) ile uygunluk göstermektedir.
Çimlenme oranları bütün yılların ortalamaları dikkate alındığında 1 nolu partide $\% 86$ ile en düşük olmuş, bunu \%88 ile 8 nolu parti ve \%89 ile 12 nolu partinin tohumları izlemiştir. En yüksek çimlenme oranlar1 ise $\% 92$ ile 3, 6 ve 7 nolu partilerden elde edilmiş, diğer partilerde ise bu oranlar \%90 ile 91 olarak elde edilmiştir (Şekil 3).

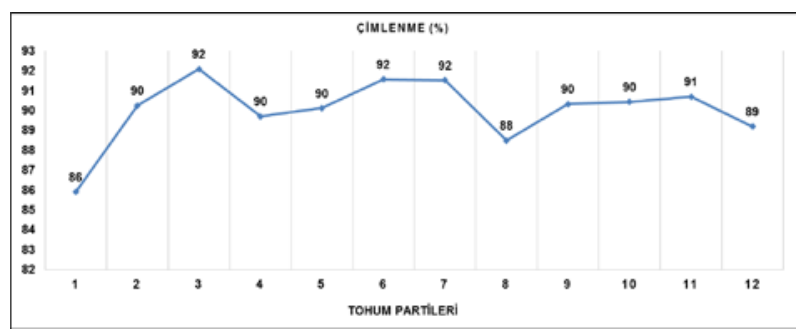

Şekil 3. İşlenmemiş şeker pancarı (Beta vulgaris L.) tohumlarında farklı tohum partilerinin çimlenme oranları (\%).

Figure 3. Germination rates (\%) of different sugar beet (Beta vulgaris L.) seed lots in unprocessed seeds

Yıllara göre bütün partilerin ortalamaları dikkate alındığında çimlenme oranları en yüksek 2007 yılında $\% 92$ olarak elde edilmiştir. Depolama süresinin uzamasıyla birlikte çimlenme oranları 2017 yılına kadar 10 yıllık bir sürede \%1-2 oranında azalmış ve \%90-91 olarak gerçekleşmiştir. 2018 yılında ise 2007 yılı ile karşılaştırıldığında tohumların çimlenme oranlarında $\% 4$ 'lük bir azalma olmuş ve çimlenme oranı \%88'e düşmüştür (Şekil 4).

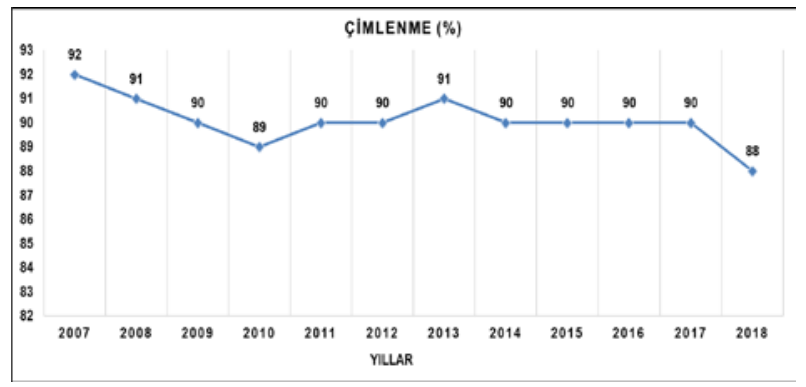

Şekil 4. İşlenmemiş şeker pancarı (Beta vulgaris L.) tohumlarının yıllara göre çimlenme oranları (\%).

Figure 4. Germination rates (\%) of unprocessed sugar beet (Beta vulgaris L.) seeds by years.

\subsection{2 İşlenmiş tohumlarda çimlenme oranları}

İşlenmiş tohumlarda çimlenme testleri 2005 ile 2018 yılları arasında 3 tohum partisinde yapılmıştır. Depolarda uzun yıllar işlenmiş bir şekilde tutulan şeker pancarı tohumlarındaki çimlenme oranları ham tohumlara göre daha yüksek olmuştur. Yapılan çimlenme testleri sonucunda 2009 y1lında 13 ve 14 nolu partiye ait tohumlar ile 2012 yılında 13 nolu partiye ait tohumların çimlenme oranları \%97 ile en yüksek olmuştur. İşlenmiş tohumlarda en düşük çimlenme 
(\%90) ise 2018 yllında 15 nolu partinin tohumlarından elde edilmiştir (Çizelge 4).

Her bir partiye ait tohumların çimlenme oranları bütün yılların ortalaması dikkate alındığında 1 ve 2 nolu partilerin tohumlarında $\% 95$ olarak elde edilmiştir. 3 nolu partinin tohumlarında çimlenme oranı $\% 93$ ile daha düşük olmuştur (Şekil 5).

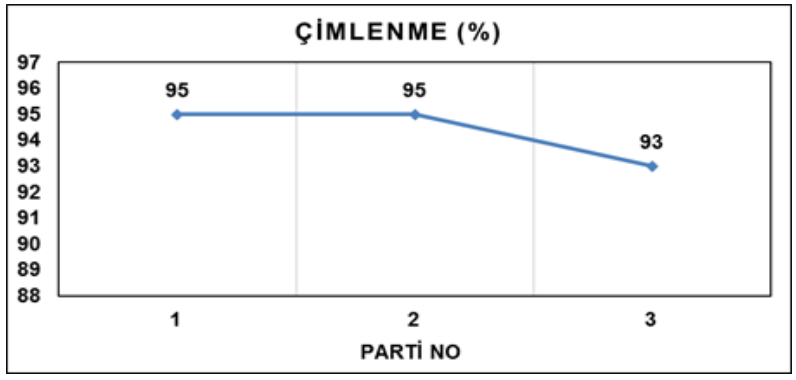

Şekil 5. İşlenmiş şeker pancarı (Beta vulgaris L.) tohumlarında farklı tohum partilerinin çimlenme oranları (\%).

Figure 5. Germination rates (\%) of different sugar beet (Beta vulgaris L.) seed lots in processed seeds.

Üç partiye ait işlenmiş tohumların ortalamalarına göre en yüksek çimlenme oranı \%96 ile 2006 yılında elde edilmiştir. $\mathrm{Bu}$ oranlar son iki yıla kadar \%1-2 oranında azalmıştır. Çimlenme oranları 2017 yılında \%4 lük bir düşüşle \%92'ye gerilemiş ve 2018 yılında ise bu oran $\% 91$ olarak elde edilmiş ve $\% 4$ lük bir azalma görülmüştür (Şekil 6).

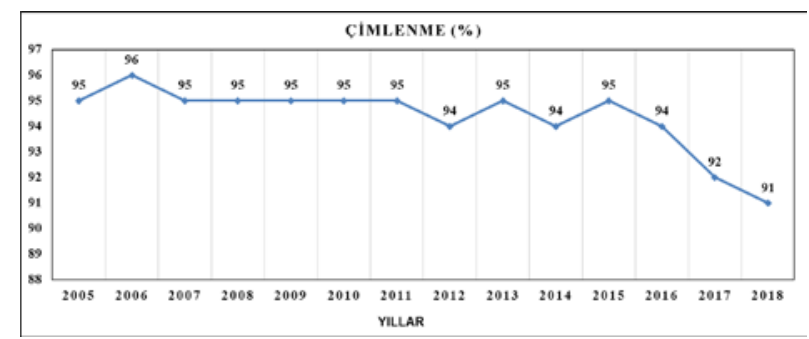

Şekil 6. İşlenmiş şeker pancarı (Beta vulgaris L.) tohumlarının yıllara göre çimlenme oranları (\%).

Figure 6. Germination rates (\%) of processed sugar beet (Beta vulgaris L.) seeds by years

İşlenmiş tohumların çimlenme oranı 2005 yılında $\% 95$ olurken bu oran 2018 yılında \%91'e düşmüştür. En yüksek çimlenme oranı 2006 y1lında \%96 olarak elde edilmiş ve 2016 yılına kadar tohumların çimlenme oranı \%94-95 arasında gerçekleşmiştir. İşlenmiş tohumların 14 y1llık depolama süresi boyunca çimlenme oranında $\% 4$ oranında bir düşüş görülmüştür (Şekil 6).

Toksik maddelerin üretimi, çimlenme fizyolojisini engelleyen en önemli nedenlerden birisidir (Leprince ve ark., 2017; Righetti ve ark., 2015; Salimi ve Boelt, 2019). Şeker pancarı tohumunun kabuğu kalın ve girintili çıkıntılı bir yapıya sahiptir. Pancarda ise bu toksik maddeler kapakçıkta (operkulum'da) ve meyve kabuğunda birikmektedir ve inhibitörler olarak bilinen bu maddeler arasında en çok dikkat çekenler fenolik bileşikler veya bunların türevleridir (Klyachenko ve ark., 2018; Wang ve ark., 2018). Bizim çimlendirme denemelerimizde de işlenmemiş ham tohumlarda çimlenme oranı işlenmiş tohumlara göre daha düşük olmuş ve işlenmiş tohumlarda perikarpta bulunan çimlenme inhibitörlerinin yıkanması ile çimlenmenin arttığını belirten Rajjou ve Debeaujon (2008) ve Orzeszko-Rywka ve ark. (2003)'nın çalışmaları ile benzerlik göstermektedir. Yıkama işlemi ile inhibitörlerin dışarı atılması, homojen ve hızlı çimlenmeyi sağlayacak fizyolojik süreçlerin teşvik edilmesi, suyun emilmesinde odunsu şeker pancarı tohumunun çimlenmesine yardımcı olmak için tohum işlemenin etkin olduğunu belirten araştırmacıların (Liu ve ark., 2018; Wozny ve ark., 2018) bulguları, işlenmiş tohumlarda elde ettiğimiz çimlenme oranının daha yüksek olduğu sonuçlarımız ile uyumludur. Ayrıca perikarpın girintili çıkıntılı kısımları da işleme sırasında uzaklaştırılarak inhibitörlerin bir kısmı bu atıklarla atılmaktadır (Zinsmeister ve ark., 2020). Bunlara ilaveten işleme sırasında boş tohumlar da atıldığından çimlenme oranı artmaktadır.

Tohum nem içeriği ise depolamada bir diğer önemli faktördür. Bizim kullandığımız tohumların nem içeriği $\% 12$ olup depolanan tohumlarda çimlenme oranını artırmada önemli rol oynamıştır. Şeker pancarında tohumların kalitesini muhafaza edebilmek için harmanlamayı takiben, \%12'den fazla nem içeren tohumların hemen kurutulması gerekmektedir (Kockelmann ve Meyer, 2006). Tohumların nem içeriği yükseldiğinde enzimlerinin aktiviteleri artmakta ve tohum kalitesinde bozulmalar yaşanmaktadır (Walters ve ark., 2005). Solberg ve ark. (2020)'nın çalışmasında ise $-20^{\circ} \mathrm{C}$ 'de depolanan tohumların nemi oldukça düşük tutulmuş (\%3-5) bu nedenle çimlenme oranı daha yüksek olmuştur.

\subsection{Serada Çimlenme Testleri}

İşlenmiş ve işlenmemiş tohumlar seralarda torf içerisinde çimlendirilmiştir. Bütün tohum partilerinde çimlenme oranlarına ait değerler \%82 ile \%94 arasında olmuştur. Laboratuvar testlerinde elde edilen sonuçlara paralel olarak sera koşullarındaki çimlendirme testlerinde de işlenmiş tohumlarda çimlenme oranları, işlenmemiş tohumlara göre daha yüksek bulunmuştur. İşlenmemiş tohumlarda en düşük çimlenme oranı $\% 82$ ile 1 nolu partiden elde edilirken en yüksek çimlenme oranı \%91 ile 6 nolu partinin tohumlarından elde edilmiştir. İşlenmiş tohumlarda ise (parti no 13-15) bu oran \%92 ila \%94 arasında gerçekleşmiştir (Şekil 7).

\subsection{Tarla Koşullarında Çimlenme Testleri}

Tarla koşullarında çimlendirme denemeleri Eskişehir ve Ilgın olmak üzere iki farklı lokasyonda yapılmıştır. Tohumların ekiminden sonra çimlenme başlangıcından 21 gün sonra çimlenen bitkiler 
sayılmıştır. İşlenmemiş tohumlarda 1 nolu partinin tohumları Eskişehir'de (\%63) ve Ilgın'da (\%80) en düşük çimlenme oranına sahip olmuştur. En yüksek çimlenme oranı Ilgın'da 8, 9, 10 ve 11; Eskişehir'de ise 9 nolu partilerin tohumlarında \%88 olmuştur (Şekil 8).

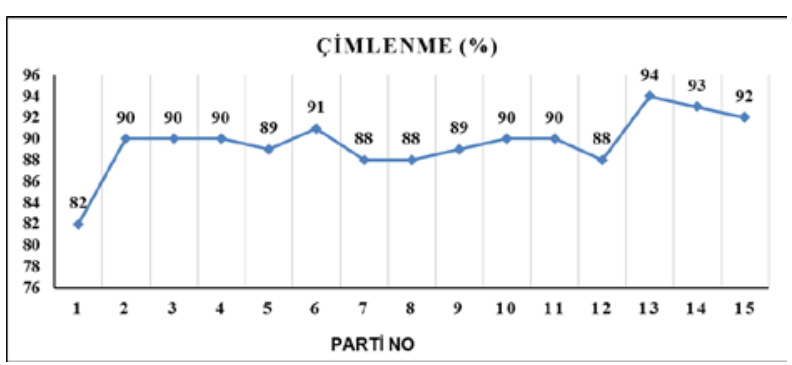

Şekil 7. Şeker pancarı (Beta vulgaris L.) tohumlarının serada çimlendirilmesi (Parti No: 1-12 işlenmemiş tohumlar, Parti no:13-15: işlenmiş tohumlar).

Figure 7. Germination of sugar beet (Beta vulgaris L.) seeds in the greenhouse (Lot \# 1-12 unprocessed seeds, Lot \# 13-15: processed seeds).

Tarladaki işlenmiş tohumların çimlenme oranları laboratuvar ve sera çimlenme testleri ile bir paralellik göstermiş ve çimlenme oranları $\% 88$ ile $\% 90$ arasında değişmiştir. Eskişehir'de yapılan denemelerde işlenmiş tohumlarda laboratuvar testlerine göre \%5-6 oranında, Ilgın'da ise \%3-5 oranında laboratuvar testlerine göre bir düşüş olmuştur (Şekil 8).

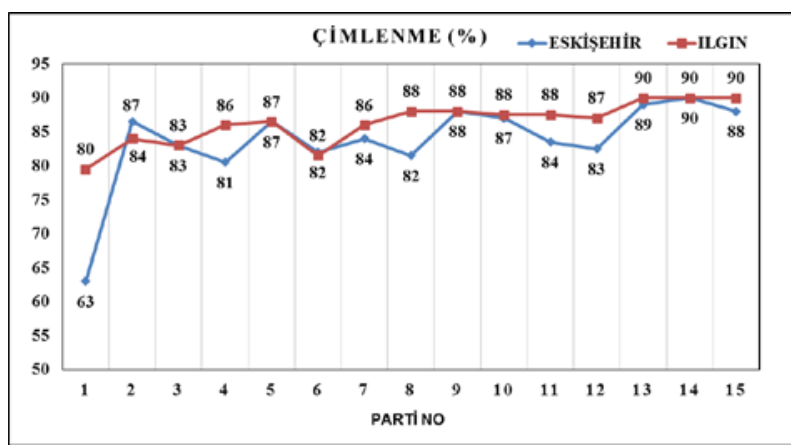

Şekil 8. Şeker pancarı (Beta vulgaris L.) tohumlarının tarlada çimlendirilmesi (Parti No: 1-12 işlenmemiş tohumlar, Parti no:13-15: işlenmiş tohumlar).

Figure 8. Germination of sugar beet (Beta vulgaris L.) seeds in the field (Lot \# 1-12 unprocessed seeds, Lot \# 13-15: processed seeds).

Laboratuarda yapilan testler, tohumun optimum koşullarda çimlenme gücüne sahip olduğunu ortaya koymaktadır. Sera ve tarla testleri tohumluk kalitesini hem genel bir değerlendirmeye tabi tutmak ve hem de bir stres testi olarak kullanılabilmektedir. Tarla koşullarında sıcaklık, toprak nemi, toprak bünyesi, toprak yapısı, tohumun tohum yatağına yerleştirilmesi ve toprak patojenleri gibi unsurların hepsi birden çıkışı etkilemektedir. Verim üzerinde doğrudan etkili olan tarladaki bitki çıkışı ise laboratuarda belirlenen değerlerden genellikle daha düşük olmaktadır (Hacıseferoğulları, 2005). Bu değerlendirmeyle uyumlu olarak tarla testlerinde elde ettiğimiz bitki çıkışları laboratuvar testlerinden elde ettiğimiz çimlenme oranlarına göre daha düşük (işlenmiş tohumlarda \%3-6) gerçekleşmiştir. Tarla çıkış oranı ekim ve sayım arasında geçen süre; ekim derinliği, toprak sıcaklığ 1 ve toprak nemine bağlıdır. Çıkış genellikle 1-4 hafta arasında gerçekleşmiştir. Çıkış testi, ilk gerçek yaprakların oluşmasını takiben, son bir bitki sayımı ile tamamlanmıştır (Kockelmann ve Meyer, 2006). Yaptığımız tarla testlerinde 15 yıllık tohumların ekilmesi ile optimum verim elde etmek için yeterli bitki sıklığı sağlanmıştır.

Ancak elde ettiğimiz sonuçlara göre, şeker pancarı tohumlarının kontrolsüz depolarda 17 yıl boyunca 1-29 ${ }^{\circ} \mathrm{C}$ ortalama sicaklıkta depolanmasi sonucunda tohumların laboratuvar, sera ve tarla koşullarında yapılan testlerde çimlenme oranının özellikle işlenmiş tohumlarda ekimlerde kullanılabilecek seviyede (\%8890) olmasının nedeni, şeker pancarı tohumlarının kalın ve sert kabuklu olması ve olumsuz koşullardan kolaylıkla etkilenmemesi ile açıklanabilir. Ayrıca Rajic ve ark. (2006)'nın yaptığ 1 çalışmada laboratuvarda altı ay süre ile sürekli \%65-75 nisbi nem ve $20^{\circ} \mathrm{C}$ sıcaklıkta yapay yaşlanma testine tabi tutulan şeker pancarı tohumlarının kalitesinin düştüğü görülmüştür. Yine aynı çalışmada silolarda kontrolsüz koşullarda saklanan şeker pancarı tohumlarının kalitesinin yapay yaşlanma testine tabi tutulan tohumlardan daha iyi olduğu belirtilmiştir. Rajic ve ark. (2006)'nın bu bulguları bizim doğal ortamlarda kontrolsüz koşullarda depo ortamı neminin (\%22-71) ve sicaklığının $\left(1-29{ }^{\circ} \mathrm{C}\right)$ kontrol edilemediği depolarda 17 y1 saklanan tohumlardan elde ettiğimiz yüksek çimlenme (işlenmiş tohumlarda \%91-93) sonuçları ile uyum halindedir.

İskandinav Gen Bankasında kullanılmayan bir maden ocağında don koşulları altında $\left(-20^{\circ} \mathrm{C}\right) 100$ yıl süre ile depolanması hedeflenen ve tohumların depo ömürlerinin incelendiği çalışmada 30 yıl süren depolama sürecinden sonra pancar tohumlarında $\% 97$ oranında çimlenme sağlanmış ve pancar tohumlarının çimlenme oranlarındaki değişim sıfir olmuştur (Solberg ve ark., 2020). Ayrica, Maude ve Bambridge (1985), kırmızı pancar tohumlarının 13 yıl süreyle $10{ }^{\circ} \mathrm{C}$ sıcaklık ve \%50 nisbi nem koşullarında saklandığında yüksek bir çimlenme seviyesini koruduğunu bildirmişlerdir. Bizim çalışmamızda ise söz konusu bu araştırmalara göre depo ortamının sıcaklığı çok yüksek olmakla birlikte başlangıçtaki çimlenme oranlarına göre işlenmiş tohumlarda çimlenme oranında \%2-6 arasında bir düşüş görülmüştür. 
Çizelge 1. Tohum depolarının en düşük ve en yüksek sıcaklık değerleri $\left({ }^{\circ} \mathrm{C}\right)$.

Table 1 . The lowest and the highest temperature values $\left({ }^{\circ} \mathrm{C}\right)$ of the seed stores.

\begin{tabular}{|c|c|c|c|c|c|c|c|c|c|c|c|c|c|c|}
\hline YILI & & OCAK & ŞUBAT & MART & NISAN & MAYIS & HAZIRAN & TEMMUZ & AĞUSTOS & EYLÜL & EКіM & KASIM & ARALIK & $\begin{array}{l}\text { ORTALAMA } \\
\text { SICAKLIK }\left({ }^{\circ} \mathrm{C}\right)\end{array}$ \\
\hline \multirow{2}{*}{2013} & EN DÜŞÜK & 3 & 9 & 9 & 14 & 19 & 25 & 22 & 23 & 17 & 10 & 6 & -1 & 13 \\
\hline & EN YÜKSEK & 8 & 12 & 16 & 23 & 21 & 30 & 25 & 26 & 24 & 21 & 14 & 8 & 19 \\
\hline \multirow{2}{*}{2014} & EN DÜŞÜK & 2 & 2 & 6 & 9 & 14 & 18 & 23 & 25 & 16 & 12 & 8 & 3 & 12 \\
\hline & EN YÜKSEK & 7 & 10 & 12 & 18 & 21 & 24 & 27 & 28 & 27 & 18 & 17 & 11 & 18 \\
\hline \multirow{2}{*}{2015} & EN DÜşÜK & 3 & 2 & 6 & 7 & 14 & 17 & 21 & 23 & 23 & 12 & 8 & 1 & 11 \\
\hline & EN YÜKSEK & 6 & 9 & 10 & 14 & 26 & 23 & 31 & 31 & 28 & 23 & 14 & 8 & 19 \\
\hline \multirow{2}{*}{2016} & EN DÜŞÜK & 1 & 3 & 6 & 10 & 15 & 17 & 23 & 21 & 17 & 13 & 6 & 1 & 11 \\
\hline & EN YÜKSEK & 9 & 11 & 12 & 20 & 21 & 30 & 30 & 31 & 27 & 22 & 14 & 8 & 20 \\
\hline \multirow{2}{*}{2017} & EN DÜŞÜK & 1 & 1 & 7 & 8 & 15 & 16 & 25 & 25 & 21 & 12 & 7 & 2 & 12 \\
\hline & EN YÜKSEK & 5 & 9 & 15 & 18 & 20 & 26 & 30 & 31 & 30 & 20 & 14 & 11 & 19 \\
\hline \multirow{2}{*}{2018} & EN DÜŞÜK & 2 & 3 & 5 & 10 & 17 & 19 & 22 & 22 & 20 & 13 & 8 & 1 & 12 \\
\hline & EN YÜKSEK & 8 & 9 & 15 & 18 & 22 & 28 & 29 & 28 & 28 & 22 & 16 & 8 & 19 \\
\hline \multirow{2}{*}{ ORTALAMA - } & EN DÜŞÜK & 2 & 3 & 7 & 10 & 16 & 19 & 23 & 23 & 19 & 12 & 7 & 1 & 12 \\
\hline & EN YÜKSEK & 7 & 10 & 13 & 19 & 22 & 27 & 29 & 29 & 27 & 21 & 15 & 9 & 19 \\
\hline
\end{tabular}

Çizelge 2. Tohum depolarının en düşük ve en yüksek nisbi nem değerleri (\%).

Table 2. The lowest and the highest relative humidity values (\%) of the seed stores.

\begin{tabular}{|c|c|c|c|c|c|c|c|c|c|c|c|c|c|c|}
\hline YILI & & OCAK & ŞUBAT & MART & NISAN & MAYIS & HAZIRAN & TEMMUZ & AĞUSTOS & EYLÜL & EKIM & KASIM & ARALIK & $\begin{array}{c}\text { ORTALAMA } \\
\text { NEM (\%) }\end{array}$ \\
\hline \multirow{2}{*}{2013} & EN DÜŞÜK & 16 & 28 & 14 & 27 & 23 & 19 & 21 & 30 & 30 & 32 & 38 & 41 & 27 \\
\hline & EN YÜKSEK & 38 & 41 & 43 & 50 & 42 & 28 & 41 & 44 & 48 & 55 & 74 & 65 & 47 \\
\hline \multirow{2}{*}{2014} & EN DÜşÜK & 62 & 48 & 40 & 38 & 43 & 40 & 32 & 30 & 26 & 34 & 38 & 50 & 40 \\
\hline & EN YÜKSEK & 82 & 76 & 69 & 64 & 70 & 70 & 43 & 47 & 52 & 69 & 66 & 73 & 65 \\
\hline \multirow{2}{*}{2015} & EN DÜşÜK & 58 & 48 & 49 & 31 & 20 & 35 & 16 & 20 & 17 & 36 & 28 & 47 & 34 \\
\hline & EN YÜKSEK & 75 & 76 & 80 & 71 & 63 & 64 & 54 & 47 & 43 & 62 & 64 & 67 & 64 \\
\hline \multirow{2}{*}{2016} & EN DÜşÜK & 42 & 45 & 41 & 30 & 36 & 26 & 20 & 20 & 20 & 25 & 30 & 34 & 31 \\
\hline & EN YÜKSEK & 80 & 85 & 65 & 54 & 60 & 52 & 36 & 40 & 44 & 45 & 56 & 60 & 56 \\
\hline \multirow{2}{*}{2017} & EN DÜşÜK & 38 & 37 & 28 & 24 & 30 & 30 & 20 & 21 & 17 & 25 & 31 & 40 & 28 \\
\hline & EN YÜKSEK & 70 & 78 & 65 & 57 & 53 & 58 & 39 & 35 & 35 & 49 & 56 & 70 & 55 \\
\hline \multirow{2}{*}{2018} & EN DÜșÜK & 50 & 49 & 48 & 31 & 30 & 30 & 22 & 24 & 22 & 30 & 33 & 42 & 34 \\
\hline & EN YÜKSEK & 68 & 70 & 73 & 55 & 58 & 54 & 43 & 43 & 44 & 56 & 63 & 67 & 58 \\
\hline \multirow{2}{*}{ ORTALAMA } & EN DÜșÜK & 44 & 43 & 37 & 30 & 30 & 30 & 22 & 24 & 22 & 30 & 33 & 42 & 32 \\
\hline & EN YÜKSEK & 69 & 71 & 66 & 59 & 58 & 54 & 43 & 43 & 44 & 56 & 63 & 67 & 58 \\
\hline
\end{tabular}

Çizelge 3. Farklı şeker pancarı (Beta vulgaris L.) tohum partilerindeki işlenmemiş (ham) tohumların ortalama çimlenme oranları (\%).

Table 3. Mean germination rate (\%) of raw (unprocessed) sugar beet (Beta vulgaris L.) seeds in different seed lots.

\begin{tabular}{|c|c|c|c|c|c|c|c|c|c|c|c|c|c|}
\hline \multirow{2}{*}{ PARTİ NO } & \multicolumn{12}{|c|}{ YILLAR } & \multirow{2}{*}{ ORTALAMA } \\
\hline & 2007 & 2008 & 2009 & 2010 & 2011 & 2012 & 2013 & 2014 & 2015 & 2016 & 2017 & 2018 & \\
\hline 1 & 85 & 84 & 83 & 82 & 86 & 87 & 87 & 88 & 87 & 87 & 87 & 85 & 86 \\
\hline 2 & 90 & 88 & 90 & 89 & 90 & 93 & 92 & 90 & 90 & 89 & 90 & 89 & 90 \\
\hline 3 & 95 & 95 & 93 & 93 & 94 & 90 & 92 & 92 & 93 & 90 & 89 & 88 & 92 \\
\hline 4 & 91 & 90 & 87 & 86 & 89 & 92 & 92 & 92 & 92 & 90 & 89 & 87 & 90 \\
\hline 5 & 93 & 90 & 91 & 90 & 90 & 88 & 90 & 90 & 90 & 91 & 91 & 88 & 90 \\
\hline 6 & 93 & 94 & 92 & 93 & 89 & 93 & 91 & 91 & 92 & 92 & 91 & 90 & 92 \\
\hline 7 & 91 & 91 & 90 & 88 & 91 & 92 & 93 & 92 & 92 & 93 & 93 & 92 & 92 \\
\hline 8 & 92 & 90 & 89 & 89 & 86 & 86 & 89 & 89 & 87 & 88 & 89 & 87 & 88 \\
\hline 9 & 92 & 93 & 91 & 91 & 91 & 92 & 90 & 87 & 90 & 89 & 89 & 88 & 90 \\
\hline 10 & 92 & 94 & 90 & 90 & 90 & 92 & 91 & 89 & 89 & 90 & 90 & 89 & 90 \\
\hline 11 & 94 & 91 & 93 & 91 & 92 & 87 & 91 & 90 & 91 & 90 & 90 & 89 & 91 \\
\hline 12 & 93 & 91 & 92 & 91 & 89 & 89 & 90 & 87 & 84 & 87 & 88 & 89 & 89 \\
\hline ORTALAMA & 92 & 91 & 90 & 89 & 90 & 90 & 91 & 90 & 90 & 90 & 90 & 88 & \\
\hline
\end{tabular}


Çizelge 4. Farklı şeker pancarı (Beta vulgaris L.) tohum partilerindeki işlenmiş tohumların ortalama çimlenme oranları (\%).

Table 4. Average germination rates (\%) of processed sugar beet (Beta vulgaris L.) seeds in different seed lots.

\begin{tabular}{|c|c|c|c|c|c|c|c|c|c|c|c|c|c|c|c|}
\hline \multirow{2}{*}{ PARTÍ NO } & \multicolumn{14}{|c|}{ YILLAR } & \multirow{2}{*}{ ORTALAMA } \\
\hline & 2005 & 2006 & 2007 & 2008 & 2009 & 2010 & 2011 & 2012 & 2013 & 2014 & 2015 & 2016 & 2017 & 2018 & \\
\hline 13 & 94 & 96 & 96 & 96 & 97 & 94 & 93 & 97 & 94 & 93 & 96 & 95 & 94 & 92 & 95 \\
\hline 14 & 94 & 96 & 98 & 95 & 97 & 96 & 96 & 94 & 96 & 95 & 96 & 93 & 93 & 92 & 95 \\
\hline 15 & 96 & 96 & 93 & 95 & 92 & 94 & 95 & 93 & 94 & 95 & 94 & 94 & 91 & 90 & 93 \\
\hline ORTALAMA & 95 & 96 & 95 & 95 & 95 & 95 & 95 & 94 & 95 & 94 & 95 & 94 & 92 & 91 & \\
\hline
\end{tabular}

\section{Sonuç}

$\mathrm{Bu}$ çalışmada elde edilen sonuçlar, depolama ömrünün çok fazla uzamasının tohum canlılığı üzerindeki etkisinin negatif olduğunu göstermektedir. Düşük sıcaklıklarda bile saklanan tohumların canlılığı zamanla azalmaktadır. Şeker pancarı tohumlarının kalın ve sert olan kabukları nedeniyle depolamaya uzun süre dayanabildikleri görülmektedir. Daha düşük sıcaklık ve nem değerlerinde depolama koşullarının modifikasyonu ile şeker pancarı tohumunun uzun yıllar bozulmadan depolanması mümkün görülmektedir. Şeker pancarı ve yabani pancar tohumlarının maksimum depolanma potansiyeli uzun vadeli sslah çalışmalarına ve bitkilerin korunmasına önemli katkılar sağlayacaktır. Düşük nem içeriğine sahip tohumların, uygun şekilde paketlenerek, nem ve sicaklık değerlerinin kontrol edildiği depolarda saklanması ile ilgili daha detaylı araştırmaların yapılması gerekmektedir.

\section{Kaynaklar}

Arın, L. 2018. Tohum depolama. Türktob, 26:8-10.

Blunk, S., Malik, A.H., de Heer, M.I., Eklabad, T., Bussell J., Sparkes D., Fredlund K., Sturrock C., Mooney S. 2017. Quantification of seed-soil contact of sugar beet (Beta vulgaris) using X-ray Computed Tomography. Plant Methods, 13:71. https://doi.org/ 10.1186/s13007-017-0220-4

Chomontowski, C., Wzorek, H., Podlaski, S. 2020. Impact of sugar beet seed priming on seed quality and performance under diversified environmental conditions of germination, emergence and growth. Journal of Plant Growth Regulation, 39:183-189. https://doi.org/10.1007/s00344-019-09973-2.

Copeland, L.O., McDonald, M.B. 2001. Seed Longevity and Deterioration. Copeland LO, McDonald MB. (eds.). Principles of seed science and technology. 4th edn. Norwell, Massachusetts: Kluwer Academic Publishers, pp. 181-220.

Hacıseferogulları, H. 2005. Vakumlu tip pnömatik hassas ekim makinası ile şeker pancarı ekiminde sıra üzeri bitki dağılım düzgünlüğü ve tarla çıkış oranları üzerine ekim mesafelerinin ve ilerleme hızlarının etkisi. S.Ü. Ziraat Fakültesi Dergisi, 19(35):30-40.

Harrington, J.F. 1973. Biochemical Basis of Seed Longevity. Seed Science \&Technology, 1:453-461.

ISTA. 1985. International Rules for Seed Testing. The International Seed Testing Association (ISTA),
Zürich, Switzerland. Seed Science and Technology,13 (2):299-513.

Kameswara, R, N., Dulloo, M.E., Engels, J.M.M. 2017. A review of factors that influence the production of quality seed for long-term conservation in genebanks. Genet. Resour. Crop Evol., 64:10611074. https://doi.org/10.1007/s10722-016-0425-9

Klyachenko, O., Likhanov, A., Volodymyr, G. 2018. Tissue and biochemical barriers of sugar beet (Beta vulgaris L. Provar. Altissima doell.) Pericarp. Journal of Microbiology, Biotechnology and Food Sciences. 8(1):663-667.

Kockelmann, A., Meyer, U. 2006. Seed Production and Quality. In: Draycott, A.P. (ed). Sugar beet. Blackwell Publishing Oxford, pp. 89-113.

Kockelmann, A., Tilcher, R., Fischer, U. 2011. Seed Production and Processing. Sugar Tech, 12:267275. https://doi.org/10.1007/s12355-010-0039-z

Leprince, O., Pellizzaro, A., Berriri, S., Buitink, J. 2017. Late seed maturation: drying without dying. Journal of Experimental Botany, 68:827-841. https://doi.org/10.1093/jxb/erw363

Li, D.Z., Pritchard, H.W. 2009. The science and economics of ex situ plant conservation. Trends in Plant Science, 14:614-621. https://doi.org/10.1016/ j.tplants.2009.09.005

Liu, W., Pan, X., Li, Y., Duan, Y., Min, J., Liu, S., Sheng, X., Li, X. 2018. Detection and validation of QTL $\mathrm{s}$ associated with seed longevity in rice (Oryza sativa L.). Plant Breeding, 137:546-552. https:// doi.org/10.1111/pbr.12611.

Long, R.L., Gorecki, M.J., Renton, M., Scott, J.K., Colville, L., Goggin, D.E., Commander D.A., Westcott H.C., William E. 2015. The ecophysiology of seed persistence: a mechanistic view of the journey to germination or demise. Biological Rev., 90:31-59. https://doi.org/10.1111/brv.12095

Longden, P.C. 1986. Influence of the seed crop environment on the quality of sugar beet seed. Proc. 49th IIRB Congress, Brussels, pp. 1-16.

Maude, R.B., Bambridge, J.M. 2007. Effects of seed treatments and storage on the incidence of Phoma betae and the viability of infected red beet seeds. Plant Pathology, 34:435-437. https://doi.org/ 10.1111/j.1365-3059.1985.tb01384.x.

Merritt, D.J., Martyn, A.J., Ainsley, P., Young, R.E., Seed, L.U., Thorpe, M. 2014. A continental-scale study of seed lifespan in experimental storage 
examining seed, plant, and environmental traits associated with longevity. Biodivers. Conserv., 23:1081-1104. https://doi.org/10.1007/s10531-0140641-6.

Milford, G. 2006. Plant structure and crop physiology. In: Draycott, A.P. (Ed), Sugar Beet. Blackwell Publishing Ltd. Oxford, pp. 30-49.

Orzeszko-Rywka, A., Podlaski, S, 2003. The efect of sugar beet seed treatments on their vigour. Plant, Soil and Environment, 49(6):249-254.

Priestley, D.A. 1986. Seed aging: implications for seed storage and persistence in the soil. NCROL; 1st Edition (April 1, 1986).

Rajjou, L, Debeaujon, I. 2008. Seed longevity: survival and maintenance of high germination ability of dry seeds. Comptes Rendus Biologies, 331:796-805.

Righetti, K., Vu, J.L., Pelletier, S., Vu, B.L., Glaab, E., Lalanne, D. 2015. Inference of longevity related genes from a robust coexpression network of seed maturation identifies regulators linking seed storability to biotic defense-related pathways. Plant Cell, 27:2692-2708. https://doi.org/10.1105/tpc.15. 00632

Salimi, Z., Boelt, B. 2019. Classification of processing damage in sugar beet (Beta vulgaris) seeds by multispectral image analysis. Sensors, 19 (10):2360. https://doi.org/10.3390/s19102360

Sarıpınar, Z. 2011. Şeker pancarı tohumluğunda elektrostatik ayırma olanakları. Yüksek Lisans Tezi. Ankara Üniversitesi Fen Bilimleri Enstitüsü, 71s, Ankara.

Sektör Raporu. 2019. Türkșeker 2020. Ankara. https://www.turkseker.gov.tr/data7dokumanlar/2019 _ Sektor_Raporu.pdf. (Erişim tarihi: 27 Temmuz 2020).

Sliwinska, E., Jing, H.C., Job, C., Job, D., Bergervoet, J.H.W., Bino, R.J., Groot, S.P.C. 1999. Effect of harvest time and soaking treatment on cell cycle activity in sugar-beet seeds. Seed Science Research, 9:91-99.

Solberg, S.Ø., Yndgaard F, Andreasen C, Bothmer R, Loskutov I.G., Asdal A. 2020. Long-Term Storage and Longevity of Orthodox Seeds: A Systematic Review. Frontiers in Plant Sciences, 11:1007. https://doi.org/10.3389/fpls.2020.01007

Steinbrecher, T, Leubner-Metzger G. 2017. The biomechanics of seed germination. Journal of Experimental Botany, 68(4):765-783. https://doi.org/ 10.1093/jxb/erw428.

Şehirali, S. 1997. Tohumluk ve Teknolojisi, Trakya Üniversitesi Ziraat Fakültesi Yayınları. Tekirdağ.

Walters, C., Wheeler, L.M. and Grotenhuis, J.M. 2005. Longevity of seeds stored in a genebank: species characteristics. Seed Science Resarch, 1:1-20. https://doi.org/10.1079/SSR2004195

Wang, T., Hou, L., Jian, H., Di, F., Li, J. and Liu, L. 2018. Combined QTL mapping, physiological and transcriptomic analyses to identify candidate genes involved in Brassica napus seed aging. Molecular Geneticts and Genomics, 293:1421-1435. https:// doi.org/10.1007/s00438-018-1468-8

Wozny, D., Kramer, K., Finkemeier, I., Acosta, I.F., Koornneef, M. 2018. Genes for seed longevity in barley identified by genomic analysis on near isogenic lines. Plant Cell Environ., 41:1895-1911. https://doi.org/10.1111/pce.13330

Zinsmeister, J., Leprince O., Buitink J. 2020. Molecular and environmental factors regulating seed longevity. Biochemical Journal, 477:305-323. https://doi.org/ 10.1042/BCJ20190165 